\title{
Pengaruh Penggunaan Lahan, Sumber Pencemar dan Tipe Vegetasi Riparian terhadap Kualitas Air Sungai Code Daerah Istimewa Yogyakarta
}

\author{
The Effect of Land Use, Pollutant Sources and Riparian Vegetation Types on Water \\ Quality of Code River Yogyakarta
}

\author{
Reksi Njurumay $^{1}$, Djoko Rahardjo ${ }^{1^{*}}$, dan Kisworo ${ }^{1}$ \\ ${ }^{1}$ Fakultas Bioteknologi, Universitas Kristen Duta Wacana, Yogyakarta, Indonesia
}

\begin{abstract}
Abstrak
Sebagai salah satu sungai besar di Provinsi Daerah Istimewa Yogyakarta, kualitas air Sungai Code banyak ditentukan oleh pengaruh aktivitas manusia dan kondisi alamiah yang ada disekitarnya. Penelitian ini bertujuan untuk mengetahui hubungan antara tataguna lahan, tipe vegetasi riparian, dan sumber bahan pencemar terhadap kualitas air sungai Code. Metode penelitian yang digunakan adalah purposive sampling. Parameter yang diukur terdiri dari parameter fisik, kimia, dan biologi. Parameter fisik sungai meliputi kedalaman, kekeruhan, kecerahan, kecepatan arus, debit air, suhu, tipe substrat, TSS, dan TDS. Parameter kimia sungai meliputi pH, DO, BOT, nitrat, fosfat, dan amonia. Parameter biologi meliputi vegetasi riparian dengan indeks biotik meliputi kerapatan, indeks kekayaan jenis, dan indeks keanekaragaman jenis. Penggunaan lahan di sungai Code didominasi oleh pembangunan (tanggul,pemukiman), pertanian dan jalan. Aktivitas masyarakat didominasi oleh aktivitas bertani dan penambangan pasir. Jenis sumber pencemar yang dominan adalah limbah rumah tangga.Karakteristik lingkungan di sungai Code adalah berbatu dan berpasir. Ditemukan 36 spesies, 25 famili, 23 ordo, 4 kelas, dan 2 divisi. Struktur komunitas vegetasi riparian didominasi oleh famili Poaceae, Asteraceae dan Malvaceae. Penggunaan lahan, pola aktivitas dan sumber pencemar dapat mempengaruhi kualitas air sungai Code (parameter fisik dan kimia). Keberadaan struktur komunitas vegetasi riparian dapat mempengaruhi kualitas air sungai Code khususnya pada parameter BOT dan Nitrat air sungai Code.
\end{abstract}

Kata kunci : penggunaan lahan,sumber pencemar,vegetasi riparian, kualitas air sungai, monitoring, sungai Code

\begin{abstract}
As one of main rivers in the Province of Special Region of Yogyakarta, water quality of Code River is largely influenced by human activities and natural conditions that surround it. This study aimed to determine the correlation between land use, riparian vegetation types, and sources of pollutants on water quality of the Code river. The purposive sampling method was used in this experiment. Measured parameters consist of physical, chemical and biological parameters. Physical parameters of the river included depth, turbidity, brightness, current velocity, water discharge, temperature, substrate type, TSS and TDS level. Chemical parameters of the river included $p H, D O, B O T$, nitrate, phosphate, and ammonia. Biological parameters of riparian vegetation was measured on biotic index consist of density, species richness index, and species diversity index. Land use in the Code river is dominated by physical development (dykes, settlements), agriculture and roads. Community activities are dominated by farming and sand mining activities. The dominant type of pollutant source is household waste. Physical environmental characteristics of Code river are rocky and sandy. Types of vegetation in Code river were formed by 36 species, 25 families, 23 orders, 4 classes, and 2 divisions. The riparian vegetation community structure is dominated by Poaceae, Asteraceae and Malvaceae families. Land use, activity patterns and sources of pollutants can affect Code river water quality (physical and chemical parameters), The structure of riparian vegetation could affected Code river water quality, especially on total organic matter and nitrate levels.
\end{abstract}

Keywords: land use, pollutant sources, riparian vegetation, river water quality, monitoring, Code River

\footnotetext{
*Corresponding Author:

Djoko Rahardjo

Fakultas Bioteknologi Universitas Kristen Duta Wacana

Jl. Wahidin Sudirohusodo 5-25 Yogyakarta, Indonesia 55224

Email : djoko@staff.ukdw.ac.id,
} 


\section{Pendahuluan}

Sungai Code merupakan salah satu sungai utama yang mengalir di Provinsi Daerah Istimewa Yogyakarta. Sungai ini bermata air di Gunung Merapi dan mempunyai daerah aliran sungai (DAS) di wilayah Kabupaten Sleman, Kotamadya Yogyakarta dan Kabupaten Bantul (Anonim, 2008). Interaksi masyarakat dengan daerah aliran sungai (DAS) Code berdampak pada kualitas air sungai Code tersebut. Pembuangan sampah dan limbah, baik dari rumah tangga ataupun kegiatan usaha, secara langsung ke badan sungai menjadi sumber pencemar utama Sungai Code. (Shoolikhah et al, 2014). Selain itu, meningkatnya aktivitas ekonomi yang terwujud dalam pemanfaatan ruang pada kawasan bantaran sungai terkadang menyebabkan tidak terkontrolnya persebaran bangunan pada DAS Code yang dapat mempengaruhi penurunan kualitas sungai.

Sempadan sungai (zona riparian) merupakan ruang di kiri dan kanan palung sungai di antara garis sempadan dan tepi palung sungai (Anonim, 2015). Zona riparian adalah ekosistem peralihan dari ekosistem akuatik ke ekosistem terestrial (Wenger, 1999). Vegetasi zona riparian didominasi oleh tanaman seperti rumput, semak, dan pohon (Semiun et al, 2013). Vegetasi ekosistem riparian merupakan salah satu komponen ekosistem yang memiliki peran penting untuk menjaga kualitas air karena mempunyai peran dalam siklus oksigen, nitrogen, karbon dan air (Rachmawati \& Retnaningdyah, 2014).

Melihat banyaknya fungsi dan manfaat vegetasi riparian, penelitian tentang pengaruh struktur vegetasi riparian untuk terhadap kondisi kualitas air suatu sungai perlu untuk dilakukan. Penelitian ini bertujuan untuk mengetahui hubungan antara tataguna lahan, tipe vegetasi riparian, dan sumber bahan pencemar terhadap kualitas air sungai Code.

\section{Materi dan Metode}

Penelitian ini dilakukan pada bulan Februari - April 2020. Pengukuran parameter kualitas air serta identifikasi vegetasi riparian yang dilakukan di Laboratorium Fakultas Bioteknologi UKDW. Alat yang digunakan untuk mengambil data vegetasi riparian adalah meteran, patok, tali rafia, kamera, dan alat tulis. Kemudian untuk alat dan bahan untuk pengambilan data kualitas air sungai, meliputi termometer, bola pingpong, rol meter, dan stopwatch, rol meter, turbidity, Secchi Disk, DO kit (NaOH-NaI, $\mathrm{Na}_{2} \mathrm{~S}_{2} \mathrm{O}_{3}$, $\mathrm{H}_{2} \mathrm{SO}_{4^{\prime}} \mathrm{MnSO}_{4^{\prime}}$ dan Amilum), pipet ukur, dan erlenmeyer. Larutan $\mathrm{NaC}_{2} \mathrm{O}_{4} 0,01 \mathrm{~N}, \mathrm{H}_{2} \mathrm{SO}_{4}$ $4 \mathrm{~N}, \mathrm{KMnO}_{4} 0,01 \mathrm{~N}$, buret, statis, erlenmeyer, hot plate, pipet ukur, dan pro pipet, $\mathrm{pH}$ meter, TDS meter. Kertas saring, oven, dan neraca analitik. Botol sampel $500 \mathrm{ml}$ sebanyak 36 buah untuk menyimpan sampel air. Alat yang digunakan untuk mendapatkan data pola aktivitas dan sumber pencemar adalah kamera, dan alat yang digunakan untuk mengambil data penggunaan lahan adalah kamera dan aplikasi Google Earth.

\section{Parameter Penelitian}

Parameter penelitian yang diukur terdiri dari parameter fisik, kimia, dan biologi. Parameter fisik sungai meliputi kedalaman, kekeruhan,kecerahan, kecepatan arus, debit air, suhu, tipe substrat, TSS, dan TDS. Parameter kimia sungai meliputi derajat keasaman (pH), DO, BOT, nitrat, fosfat, dan amonia. Parameter biologi (vegetasi riparian) meliputi kerapatan, indeks kekayaan jenis, dan indeks keanekaragaman jenis.

\section{Jenis Sampel dan Teknik Pencuplikan Sampel}

Sampel yang dicuplik berupa sampel air dan sampel vegetasi. Sampel air diambil pada setiap lokasi pencuplikan dengan menggunakan metode purposive sampling untuk mengetahui kualitas air sungai Code. Sampel vegetasi diamati dengan teknik plotting. Teknik observasi digunakan untuk mengetahui potret penggunaan lahan dan sumber bahan pencemar yang masuk ke aliran sungai Code.

\section{Pengukuran Parameter}

1. Parameter Fisik

a. Kedalaman air

Kedalaman air sungai diukur dengan menggunakan rol meter yang dimasukkan secara tegak lurus hingga menyentuh 
dasar perairan, lalu dicatat batas air yang ditunjukkan pada angka pada rol meter. Hasil dalam satuan sentimeter $(\mathrm{cm})$.

\section{b. Suhu}

Pengukuran suhu dilakukan menggunakan alat thermometer dengan mengacu pada SNI-06-6989.23-2005. Termometer dimasukkan ke dalam air hingga tercelup setengah dari panjang thermometer, diamkan \pm 5 menit lalu amati dalam keadaan masih di dalam air dan sejajarkan mata pada thermometer serta catat hasil temperaturnya berdasarkan garis yang dicapai oleh cairan di dalam termometer.

\section{c. Kecepatan arus}

Kecepatan arus diukur menggunakan prinsip benda apung dengan melihat durasi waktu (menit) benda tersebut dapat bergerak pada jarak tertentu. Penelitian ini menggunakan bola pingpong yang diletakkan ke permukaan air sehingga terbawa oleh arus dengan jarak tertentu, lalu catat waktu yang diperlukan untuk bola pingpong berpindah dari titik satu ke titik lainnya. Kecepatan arus dihitung dengan rumus :

$$
V=\frac{L}{t}
$$

Keterangan :

$\mathrm{V}: \operatorname{Kecepatan}(\mathrm{m} / \mathrm{s})$

L : Jarak tempuh $(\mathrm{m})$

$\mathrm{t}$ : Waktu tempuh (s)

\section{c. Debit air}

Prinsip dan penghitungan debit air mengacu pada SNI 8066 : 2015 tentang tata cara pengukuran debit aliran sungai dan saluran terbuka menggunakan alat ukur arus dan pelampung. Proses penghitungan debit air sungai melibatkan data kedalaman, kecepatan arus, lebar aliran, serta luas penampang.

$$
\begin{gathered}
\mathrm{q}_{\mathrm{x}}: \mathrm{V}_{\mathrm{x}} \mathrm{a}_{\mathrm{x}} \\
Q=\sum_{x=1}^{n} \mathrm{qx}
\end{gathered}
$$

Keterangan :

$\mathrm{q}_{\mathrm{x}}$ : Debit pada bagian ke $\mathrm{x}(\mathrm{m} 3 / \mathrm{s})$

$V_{x}$ : Kecepatan aliran rata-rata pada penampang $X(\mathrm{~m} / \mathrm{s})$

$a_{x}$ : Luas penampang basah pada bagian ke $x\left(\mathrm{~m}^{2}\right)$

$\mathrm{Q}$ : Debit seluruh penampang $\left(\mathrm{m}^{3} / \mathrm{s}\right)$

$\mathrm{n}$ : Banyaknya penampang bagian

\section{d. Kecerahan}

Kecerahan diukur menggunakan alat secchi disk dengan teknik penghitungan secara langsung atau tidak langsung disesuaikan dengan kondisi lapangan. Data kedalaman dari batas tampak secchi disk diukur kemudian dicatat.

\section{e. Kekeruhan}

Kekeruhan diukur menggunakan metode spektrofotometri dengan alat turbidity meter HACH 2100N. Pengukuran dilakukan dengan cara memasukkan sampel sebanyak $100 \mathrm{ml}$ pada tabung sampel yang ada dalam turbidity meter. Angka yang didapatkan adalah nilai kekeruhan air dengan satuan nefelometrik turbidity unit (NTU).

\section{f. Tipe substrat}

Tipe atau jenis substrat diketahui dengan cara observasi, pengambilan sampel sedimen dan penentuan proporsi komposisi sedimen yang dominan pada setiap titik sampling.

\section{g. TSS (Total Suspended Solid)}

Pengukuran kadar TSS dilakukan dengan metode gravimetri menggunakan kertas saring berukuran 0,45 $\mu \mathrm{m}$. Kertas saring yang telah dikeringkan dalam oven selama 2 jam bersuhu $180^{\circ} \mathrm{C}$ kemudian ditimbang. Kertas saring yang telah ditimbang kemudian digunakan untuk menyaring sampel air sebanyak $100 \mathrm{ml}$, lalu setelah itu kertas saring dimasukkan kembali ke dalam oven bersuhu $180^{\circ} \mathrm{C}$ selama 2 jam dan dilakukan penimbangan kembali. Selisih dari hasil penimbangan kertas saring sebelum dan setelah menyaring sampel merupakan hasil dari padatan yang tersuspensi atau TSS dalam satuan gram per $100 \mathrm{ml}$. 
h. TDS (Total Dissolved Solid)

Pengukuran kadar TDS atau padatan terlarut menggunakan metode daya hantar listrik (DHL) dengan alat TDS meter. Penggunaan TDS meter dengan cara dicelupkan pada sampel hingga batang besi tercelup seluruhnya. Kandungan padatan terlarut yang terukur akan muncul pada monitor dalam satuan part per million (ppm).

\section{Parameter Kimia}

a. $\mathrm{pH} /$ Derajat Keasaman

Derajat keasaman air dapat dideteksi menggunakan alat $\mathrm{pH}$ meter. Penggunaan $\mathrm{pH}$ meter adalah dengan cara mencelupkannya ke dalam sampel air selama beberapa saat hingga angka pada monitor stabil.

\section{b. Bahan Organik Total (BOT)}

Bahan organik total diukur dengan angka permanganat metode titimetric. Sampel sebanyak $100 \mathrm{~mL}$ dalam Erlenmeyer ditambahkan beberapa tetes larutan baku $\mathrm{KMnO}_{4} 0,01 \mathrm{~N}$ hingga terbentuk warna merah muda. Ke dalam sampel ditambahkan lagi 5 $\mathrm{ml} \mathrm{H}_{2} \mathrm{SO}_{4} 4 \mathrm{~N}$. Larutan kemudian dididihkan selama 1 menit. Selanjutya kedalam larutan ditambahkan $10 \mathrm{ml}$ larutan baku $\mathrm{KMnO}_{4}$ $0,01 \mathrm{~N}$, dipanaskan kembali hingga mendidih selama 10 menit hingga terbentuk warna konstan. Sebanyak $10 \mathrm{ml}$ larutan baku $\mathrm{H}_{2} \mathrm{C}_{2} \mathrm{O}_{4} 0,01 \mathrm{~N}$ ditambahkan ke dalam larutan lalu dipanaskan kembali hingga mendidih. Titrasi dilakukan dengan larutan baku $\mathrm{KMnO}_{4} 0,01 \mathrm{~N}$ hingga terbentuk warna merah muda konstan.

Perhitungan dengan metode TOM (Total Organic Material) menggunakan rumus beikut :

$\mathrm{TOM}(\mathrm{mg} / \mathrm{l})$ :

$\frac{\left\{\left(\begin{array}{c}\text { Vol. KMNO4x } \\ \text { N KMNO4 }\end{array}\right)-\left(\begin{array}{c}\text { Vol H2C2O4x } \\ \text { N H2C2O4 }\end{array}\right)\right\} \times 31,63 \times 1000}{\text { Vol.Sampel }}$

Keterangan :

31,63 = Seperlima dari $\mathrm{BM} \mathrm{KMnO}_{4}$, tiap mol $\mathrm{KMnO}_{4}$ melepaskan 5 dalam reaksi

$\mathrm{N}=$ Normalitas $\mathrm{KMnO}_{4}$ c. DO

Pengukuran oksigen terlarut menggunakan metode Micro Winkler. Ke dalam $40 \mathrm{ml}$ sampel ditambahkan masingmasing 8 tetes larutan $\mathrm{MnSO}_{4}$ dan larutan $\mathrm{NaOH}-\mathrm{NaI}$, lalu digojog hingga berubah warna menjadi coklat keruh. Ke dalam larutan ditambahkan 8 tetes larutan $\mathrm{H}_{2} \mathrm{SO}_{4}$ lalu digojog hingga warna berubah menjadi kuning bening. Selanjutnya, ditambahkan kembali dengan sampel sebanyak $8 \mathrm{ml}$ dan didiamkan selama 15 menit. Setelah itu, larutan dititrasi dengan larutan $\mathrm{Na}_{2} \mathrm{~S}_{2} \mathrm{O}_{3}$ sampai berwarna kuning pucat, ditambahkan 3 tetes amilum $1 \%$, dan digojog hingga warna berubah menjadi biru kehitaman. Titrasi dilakukan lagi dengan larutan $\mathrm{Na}_{2} \mathrm{~S}_{2} \mathrm{O}_{3}$ hingga warna menjadi bening. Jumlah larutan $\mathrm{Na}_{2} \mathrm{~S}_{2} \mathrm{O}_{3}(\mathrm{ml})$ yang terpakai dicatat sebagai dasar perhitungan.

\section{DO $(\mathrm{ppm})=$ volume titran $\times 0,04($ skala 100$)$}

\section{d. Nitrat}

Penghitungan kadar nitrat menggunakan metode kolorimetri dengan bahan brusin sulfat mengacu pada EPA Method 352.1.

\section{e. Fosfat}

Kadar fosfat dihitung mengggunakan metode asam askorbat dengan alat spektrofotometer yang mengacu pada SNI 066989.31-2005

\section{f. Amoniak}

Penghitungan kadar ammonia dilakukan menggunakan test kit ammonia.

\section{Parameter Biologi}

Data parameter biologi didapatkan dari identifikasi vegetasi riparian menggunakan aplikasi PlantNet yang diklarifikasi melalui beberapa website yang memuat pangkalan data tanaman. Penghitungan indeks tanaman dilakukan setelah proses identifikasi. Nilai indeks tanaman yang dihitung adalah sebagai berikut : 
a. Densitas/Kerapatan

Kerapatan adalah banyaknya individu per unit area dalam hektar yang diambil dari Siahaan (2010) :

Keterangan:

$$
\mathrm{D}=10000 \mathrm{a} / \mathrm{b}
$$

$\mathrm{D}=$ Kerapatan vegetasi (ind./ha)

$\mathrm{a}=$ Jumlah vegetasi (individu)

$\mathrm{b}=$ Luas plot $\left(\mathrm{m}^{2}\right)$

b. Indeks Kekayaan Jenis

Kekayaan jenis menunjukkan banyaknya suatu jenis dalam suatu komunitas. Nilai kekayaan jenis (R) dalam suatu komunitas diukur dengan Indeks Margalef dengan rumus :

Keterangan:

$$
R=(S-1) / \ln N
$$

$\mathrm{R}=$ Nilai indeks kekayaan jenis Margalef

$\mathrm{S}=$ Jumlah jenis yang ditemukan

$\mathrm{N}=$ Jumlah total individu

\section{c. Indeks Keanekaragaman Jenis}

Keanekaragaman jenis diketahui berdasarkan indeks $\left(\mathrm{H}^{\prime}\right)$ dari ShannonWiener. Perhitungan indeks keanekaragaman jenis diambil dari Siahaan (2012), dengan rumus berikut :

$$
H^{\prime}=-\sum \text { pi Log } 2 \text { pi }
$$

Keterangan:

$\mathrm{H}^{\prime}=$ Indeks Keanekaragaman Jenis

Shannon-Wiener

$\mathrm{pi}=$ proporsi kerapatan jenis $\mathrm{ke}-\mathrm{i}=(\mathrm{ni} / \mathrm{N})$

$\mathrm{ni}=$ kerapatan jenis ke-i

$\mathrm{N}=$ kerapatan seluruh jenis

$\mathrm{K}=$ kerapatan $=\frac{\text { Iumlah Individu suatu jenis dalam plot contoh }}{\text { Lot }}$

\section{Penentuan Status Mutu Air Sungai Code}

Penentuan status mutu air mengacu pada Keputusan Menteri Negara Lingkungan Hidup No. 115 Tahun 2003 tentang pedoman penentuan status mutu air. Metode penentuan yang digunakan adalah metode penghitungan indeks pencemaran. PIj adalah indeks pencemaran bagi peruntukan (j) yang merupakan fungsi dari Ci/Lij. Nilai PIj dapat dihitung dengan menggunakan rumus :

$$
P I_{j}=\sqrt{\frac{(C i / L i j)_{M}^{2}+(C i / L i j)_{R}^{2}}{2}}
$$

Keterangan:

$\mathrm{PIj}=$ Indeks pencemaran

$(\mathrm{Ci} / \mathrm{Lij}) \mathrm{M}=$ Nilai pencemaran relatif maksimum

$(\mathrm{Ci} / \mathrm{Lij}) \mathrm{R} \quad=$ Nilai pencemaran relatif ratarata

Kelas Indeks Pencemaran ada 4 dengan skor yaitu :

\begin{tabular}{|l|l|}
\hline \multicolumn{1}{|c|}{ Range Nilai } & \multicolumn{1}{|c|}{ Keterangan } \\
\hline $\mathrm{O} \leq \mathrm{Plj} \leq 1,0$ & $\begin{array}{l}\text { Memenuhi Baku Mutu } \\
\text { (kondisi baik) }\end{array}$ \\
\hline $1,0<\mathrm{Plj} \leq 5,0$ & Cemar Ringan \\
\hline $5,0<\mathrm{Plj} \leq 10$ & Cemar Sedang \\
\hline $\mathrm{Plj}>10$ & Cemar Berat \\
\hline
\end{tabular}

\section{Analisis Data}

Analisis data dilakukan secara deskriptif kualitatif dengan bantuan software PlantNet. Analisa kuantitatif analitik dilakukan secara statistik menggunakan ANOVA untuk melihat perbedaan karakteristik fisik kimia, serta analisa korelasi pearson untuk memperkirakan hubungan antara struktur komunitas vegetasi riparian dengan kualitas air sungai Code.

\section{Hasil}

Karakteristik lingkungan, penggunaan lahan, aktivitas masyarakat, sumber dan jenis pencemar yang dicatat dalam penelitian ini tercantum pada Tabel 1.

Indeks biotik vegetasi riparian yang dihitung berdasarkan temuan di lokasi peneltian disajikan dalam Tabel 2.

Data penggunaan lahan dan struktur vegetasi riparian di daerah aliran sungai (DAS) Code disajikan dalam Gambar 1 dan 2.

Perbandingan penggunaan lahan, aktivitas sumber pencemar, struktur komunitas vegetasi riparian, kualitas air, dan status mutu air di tiap stasiun pengamatan tercantum pada Tabel 3.

Korelasi antara vegetasi riparian dengan karakteristik fisik, kimia air Sungai Code disajikan pada Tabel 4 
Tabel 1. Karakterisitik lingkungan,penggunaan lahan, aktivitas masyarakat, dan sumber pencemar.jenis pencemar

\begin{tabular}{|c|c|c|c|c|c|c|c|c|}
\hline & \multicolumn{8}{|c|}{ stasiun } \\
\hline & 1 & 2 & 3 & 4 & 5 & 6 & 7 & 8 \\
\hline $\begin{array}{l}\text { Karakter- } \\
\text { istik ling- } \\
\text { kungan }\end{array}$ & $\begin{array}{l}\text { - Tipe } \\
\text { topografi } \\
\text { landai } \\
\text { dan ter- } \\
\text { buka } \\
\text { - Tipe } \\
\text { substrat } \\
\text { berbatu, } \\
\text { pasir dan } \\
\text { berlum- } \\
\text { pur }\end{array}$ & $\begin{array}{l}\text { - Tipe } \\
\text { topografi } \\
\text { landau } \\
\text { dan } \\
\text { terbuka } \\
\text { - Tipe } \\
\text { substrat } \\
\text { berbatu, } \\
\text { pasir }\end{array}$ & $\begin{array}{l}\text { - Tipe } \\
\text { topografi } \\
\text { landai dan } \\
\text { terbuka } \\
\text { - Tipe } \\
\text { substrat } \\
\text { berbatu, } \\
\text { pasir }\end{array}$ & $\begin{array}{l}\text { - Tipe } \\
\text { topografi } \\
\text { landai } \\
\text { dan } \\
\text { terbuka } \\
\text { - Tipe } \\
\text { substrat } \\
\text { berbatu, } \\
\text { pasir }\end{array}$ & $\begin{array}{l}\text { - Tipe } \\
\text { topografi } \\
\text { landai } \\
\text { dan } \\
\text { terbuka } \\
\text { - Tipe } \\
\text { substrat } \\
\text { berbatu, } \\
\text { pasir }\end{array}$ & $\begin{array}{l}\text { - Tipe } \\
\text { topografi } \\
\text { landai } \\
\text { dan } \\
\text { terbuka } \\
\text { - Tipe } \\
\text { substrat } \\
\text { berbatu, } \\
\text { pasir }\end{array}$ & $\begin{array}{l}\text { - Tipe } \\
\text { topografi } \\
\text { curam } \\
\text { dan } \\
\text { tertutup } \\
\text { - Tipe } \\
\text { substrat } \\
\text { berbatu, } \\
\text { pasir }\end{array}$ & $\begin{array}{l}\text { - Tipe } \\
\text { topografi } \\
\text { curam dan } \\
\text { tertutup } \\
\text { - Tipe } \\
\text { substrat } \\
\text { berbatu, } \\
\text { pasir } \\
\text { berlumpur }\end{array}$ \\
\hline $\begin{array}{l}\text { Penggu- } \\
\text { naan lahan }\end{array}$ & $\begin{array}{l}\text { penamban- } \\
\text { gan pasir }\end{array}$ & $\begin{array}{l}\text { Tanggul, } \\
\text { area } \\
\text { persawahan } \\
\text { area } \\
\text { perumahan } \\
\text { bendungan. }\end{array}$ & $\begin{array}{l}\text { tanggul, } \\
\text { kolam ikan, } \\
\text { jalan dalam } \\
\text { kampung } \\
\text { kota dan } \\
\text { perumahan } \\
\text { warga }\end{array}$ & $\begin{array}{l}\text { tanggul, } \\
\text { perumahan } \\
\text { warga, } \\
\text { rumah } \\
\text { makan. }\end{array}$ & $\begin{array}{l}\text { tanggul dan } \\
\text { perumahan, } \\
\text { rumah } \\
\text { makan dan } \\
\text { kandang } \\
\text { ayam }\end{array}$ & $\begin{array}{l}\text { tanggul } \\
\text { dan jalan } \\
\text { kampung } \\
\text { kota, } \\
\text { perumahan } \\
\text { warga dan } \\
\text { warung } \\
\text { makan } \\
\end{array}$ & $\begin{array}{l}\text { tanggul } \\
\text { (terbuat } \\
\text { dari kawat) } \\
\text { dan dan } \\
\text { perumahan } \\
\text { warga }\end{array}$ & $\begin{array}{l}\text { Persawahan } \\
\text { dan } \\
\text { dibangunkan } \\
\text { tanggul }\end{array}$ \\
\hline $\begin{array}{l}\text { Sumber } \\
\text { pencemar } \\
\text { dan akti- } \\
\text { vitas }\end{array}$ & $\begin{array}{l}\text { Menggali } \\
\text { pasir }\end{array}$ & $\begin{array}{l}\text { area } \\
\text { persawahan } \\
\text { dan selokan } \\
\text { limbah } \\
\text { rumah } \\
\text { tangga dan } \\
\text { menggali } \\
\text { pasir, } \\
\text { memancing } \\
\text { serta bertani }\end{array}$ & $\begin{array}{l}\text { Limbah } \\
\text { rumah } \\
\text { tangga dan } \\
\text { tambak ikan, } \\
\text { selokan dari } \\
\text { perumahan } \\
\text { buang } \\
\text { sampah serta } \\
\text { memancing }\end{array}$ & $\begin{array}{l}\text { limbah } \\
\text { rumah } \\
\text { tangga, } \\
\text { rumah } \\
\text { makan, } \\
\text { selokan } \\
\text { dari rumah } \\
\text { warga } \\
\text { buang } \\
\text { sampah } \\
\text { dan } \\
\text { memancing }\end{array}$ & $\begin{array}{l}\text { limbah } \\
\text { rumah } \\
\text { tangga, } \\
\text { rumah } \\
\text { makan, } \\
\text { kandang } \\
\text { ayam } \\
\text { buang } \\
\text { sampah dan } \\
\text { memancing } \\
\text { berdagang }\end{array}$ & $\begin{array}{l}\text { limbah } \\
\text { rumah } \\
\text { tangga, } \\
\text { rumah } \\
\text { makan, } \\
\text { kandang } \\
\text { ayam } \\
\text { buang } \\
\text { sampah dan } \\
\text { memancing } \\
\text { berdagang }\end{array}$ & $\begin{array}{l}\text { limbah } \\
\text { rumah } \\
\text { tangga, } \\
\text { pabrik tahu } \\
\text { buang } \\
\text { sampah } \\
\text { dan } \\
\text { memancing }\end{array}$ & $\begin{array}{l}\text { Persawahan, } \\
\text { limbah rumah } \\
\text { tangga, } \\
\text { buang } \\
\text { sampah dan } \\
\text { memancing } \\
\text { bertani. }\end{array}$ \\
\hline $\begin{array}{l}\text { Jenis } \\
\text { pencemar }\end{array}$ & & $\begin{array}{l}\text { Bahan } \\
\text { organik }\end{array}$ & $\begin{array}{l}\text { Nitrat, fosfat, } \\
\text { sampah } \\
\text { palstik, } \\
\text { deterjen }\end{array}$ & $\begin{array}{l}\text { Nitrat, } \\
\text { fosfat, } \\
\text { sampah } \\
\text { palstik, } \\
\text { deterjen }\end{array}$ & $\begin{array}{l}\text { Nitrat, } \\
\text { fosfat, } \\
\text { sampah } \\
\text { palstik, } \\
\text { deterjen }\end{array}$ & $\begin{array}{l}\text { Nitrat, } \\
\text { fosfat, } \\
\text { sampah } \\
\text { palstik, } \\
\text { deterjen }\end{array}$ & $\begin{array}{l}\text { Nitrat, } \\
\text { fosfat, } \\
\text { sampah } \\
\text { palstik, } \\
\text { deterjen }\end{array}$ & $\begin{array}{l}\text { Nitrat, fosfat, } \\
\text { sampah } \\
\text { palstik }\end{array}$ \\
\hline
\end{tabular}

Tabel 2 Indeks Biotik Vegetasi Riparian di Sungai Code

\begin{tabular}{cccccc}
\hline Stasiun & $\begin{array}{c}\text { Jumlah } \\
\text { individu }\end{array}$ & $\begin{array}{c}\text { Jumlah } \\
\text { spesies }\end{array}$ & $\mathbf{H}^{\prime}$ & $\mathbf{R}$ & $\mathbf{D}$ \\
\hline 1 & 155 & 11 & 3,06 & 1,98 & 377.000 \\
2 & 227 & 6 & 2,24 & 1,00 & 567.500 \\
3 & 0 & 0 & 0 & 0 & 0 \\
4 & 0 & 0 & 0 & 0 & 0 \\
5 & 0 & 0 & 0 & 0 & 0 \\
6 & 73 & 6 & 2,14 & 1,16 & 179.500 \\
7 & 30 & 7 & 2,39 & 1,76 & 2.625 \\
8 & 209 & 11 & 2,81 & 1,87 & 372.500 \\
\hline
\end{tabular}

Keterangan : $\mathrm{H}^{\prime}$ : Indeks Keanekaragaman jenis ; R : Indeks kekayaan Jenis ; D : Kerapatan

\section{Pembahasan}

Berdasarkan hasil pengamatan karakteristik lingkungan (Tabel 1) menunjukkan area pada stasiun 1 sampai stasiun 6 mempunyai tipe topografi landai dan terbuka, sedangkan area pada stasiun 7 dan 8 memiliki tipe topografi curam dan tertutup. Berdasarkan hasil observasi penggunaan lahan,pola aktivitas dan sumber pencemar di sepanjang sungai Code (stasiun 1 - stasiun 8 ) diketahui ada keragaman penggunaan lahan, tipe aktivitas masyarakat dan tipe sumber pencemar. Hasil pengamatan pada stasiun1-8 menunjukkan beragam sumber pencemar daerah aliran sungai (DAS) Code, seperti aktivitas penambangan pasir, limbah rumah tangga, limbah kegiatan pertanian dan perikanan, limbah usaha rumah makan dan industri tahu. Limbah rumah tangga menjadi sumber pencemar dominan di sepanjang DAS Code. Hasil observasi mengenai pola aktivitas masyarakat, ditemukan aktivitas di setiap stasiun berbeda - beda.

Peraturan Pemerintah Republik Indonesia Nomor 38 Tahun 2011 tentang 
Tabel 3. Perbandingan Penggunaan Lahan,Aktivitas Sumber Pencemar, Struktur Komunitas Vegetasi Riparian, Kualitas Air, dan Status Mutu Air di Tiap Stasiun.

\begin{tabular}{|c|c|c|c|c|c|c|c|c|c|}
\hline & & \multicolumn{8}{|c|}{ Stasiun } \\
\hline & & 1 & 2 & 3 & 4 & 5 & 6 & 7 & 8 \\
\hline \multicolumn{2}{|c|}{ Penggunaan Lahan } & $\begin{array}{l}\text { penam- } \\
\text { bangan } \\
\text { pasir }\end{array}$ & $\begin{array}{l}\text { Tanggul, } \\
\text { area per- } \\
\text { sawahan } \\
\text { area pe- } \\
\text { rumahan } \\
\text { bendun- } \\
\text { gan. }\end{array}$ & $\begin{array}{l}\text { tanggul, } \\
\text { kolam } \\
\text { ikan, jalan } \\
\text { dalam } \\
\text { kampung } \\
\text { kota } \\
\text { dan pe- } \\
\text { rumahan } \\
\text { warga } \\
\end{array}$ & $\begin{array}{c}\text { tanggul, } \\
\text { perumah- } \\
\text { an warga, } \\
\text { rumah } \\
\text { makan }\end{array}$ & $\begin{array}{l}\text { tanggul } \\
\text { dan pe- } \\
\text { rumahan, } \\
\text { rumah } \\
\text { makan }\end{array}$ & $\begin{array}{l}\text { tanggul } \\
\text { dan jalan } \\
\text { kampung } \\
\text { kota, pe-- } \\
\text { rumahan } \\
\text { warga dan } \\
\text { warung } \\
\text { makan }\end{array}$ & $\begin{array}{l}\text { tanggul } \\
\text { (terbuat } \\
\text { dari } \\
\text { kawat) } \\
\text { dan dan } \\
\text { perumah- } \\
\text { an warga. }\end{array}$ & $\begin{array}{l}\text { Area per- } \\
\text { sawahan }\end{array}$ \\
\hline \multicolumn{2}{|c|}{$\begin{array}{l}\text { Aktivitas dan Jenis } \\
\text { Sumber Pencemar }\end{array}$} & $\begin{array}{l}\text { Menggali } \\
\text { pasir }\end{array}$ & $\begin{array}{l}\text { menggali } \\
\text { pasir, me- } \\
\text { mancing } \\
\text { dan ber- } \\
\text { tani. } \\
\text { Area per- } \\
\text { sawahan } \\
\text { dan selo- } \\
\text { kan lim- } \\
\text { bah rumah } \\
\text { tangga. }\end{array}$ & $\begin{array}{l}\text { buang } \\
\text { sampah } \\
\text { dan me- } \\
\text { mancing. } \\
\text { Limbah } \\
\text { rumah } \\
\text { tangga } \\
\text { dan peri- } \\
\text { kanan }\end{array}$ & $\begin{array}{l}\text { buang } \\
\text { sampah } \\
\text { dan me- } \\
\text { mancing. } \\
\text { Limbah } \\
\text { rumah } \\
\text { tangga, } \\
\text { rumah } \\
\text { makan. }\end{array}$ & $\begin{array}{l}\text { buang } \\
\text { sampah, } \\
\text { memacing } \\
\text { berda- } \\
\text { gang dan } \\
\text { bertenak } \\
\text { ayam. } \\
\text { Limbah } \\
\text { rumah } \\
\text { tangga, } \\
\text { rumah } \\
\text { makan }\end{array}$ & $\begin{array}{l}\text { buang } \\
\text { sampah, } \\
\text { memacing } \\
\text { dan berda- } \\
\text { gang. } \\
\text { Limbah } \\
\text { rumah } \\
\text { tangga, } \\
\text { rumah } \\
\text { makan dan } \\
\text { limbah } \\
\text { pertenakan } \\
\text { ayam }\end{array}$ & $\begin{array}{l}\text { buang } \\
\text { sampah } \\
\text { dan me- } \\
\text { macing. } \\
\text { Limbah } \\
\text { rumah } \\
\text { tangga dan } \\
\text { pabrik } \\
\text { tahu }\end{array}$ & $\begin{array}{l}\text { Memanc- } \\
\text { ing dan } \\
\text { bertani. } \\
\text { Persawa- } \\
\text { han dan } \\
\text { limbah } \\
\text { rumah } \\
\text { tangga }\end{array}$ \\
\hline \multicolumn{2}{|c|}{$\begin{array}{l}\text { Struktur Komunitas } \\
\text { Vegetasi Riparian }\end{array}$} & $\begin{array}{l}\text { Tersu- } \\
\text { sun atas } \\
\text { tanaman } \\
\text { bawah } \\
\text { hingga } \\
\text { sedang } \\
\text { (tiang) }\end{array}$ & $\begin{array}{l}\text { Tersu- } \\
\text { sun atas } \\
\text { tanaman } \\
\text { bawah } \\
\text { hingga } \\
\text { sedang } \\
\text { (tiang) }\end{array}$ & - & - & - & $\begin{array}{l}\text { Tersu- } \\
\text { sun atas } \\
\text { tanaman } \\
\text { bawah }\end{array}$ & $\begin{array}{l}\text { Tersu- } \\
\text { sun atas } \\
\text { tanaman } \\
\text { bawah }\end{array}$ & $\begin{array}{l}\text { Tersu- } \\
\text { sun atas } \\
\text { tanaman } \\
\text { bawah }\end{array}$ \\
\hline \multicolumn{10}{|l|}{ Kualitas Air } \\
\hline Parameter & \multicolumn{9}{|l|}{ Satuan } \\
\hline Kedalaman & $\mathrm{Cm}$ & $34^{\mathrm{abc}}$ & $27,63^{\mathrm{ab}}$ & $26,43^{a}$ & $36,67^{\mathrm{abc}}$ & $42,43^{\text {de }}$ & $32,23^{\mathrm{abc}}$ & $37,63^{\text {cde }}$ & $46,53^{e}$ \\
\hline Kec. Arus & $\mathrm{M} / \mathrm{s}$ & $0,43^{b}$ & $0,193^{\mathrm{a}}$ & $0,713^{\text {cde }}$ & $0,73^{\text {de }}$ & $0,53^{\mathrm{bc}}$ & $0,86^{\mathrm{e}}$ & $0,57 b^{c d}$ & $0,82^{\mathrm{e}}$ \\
\hline Debit Air & $\mathrm{M}^{3} / \mathrm{s}$ & $0,44^{\mathrm{a}}$ & $0,55^{\mathrm{a}}$ & $2,16^{a}$ & $3,95^{\mathrm{a}}$ & $3,85^{\mathrm{a}}$ & $3,16^{\mathrm{a}}$ & $2,48^{\mathrm{a}}$ & $2,56^{\mathrm{e}}$ \\
\hline Suhu & ${ }^{0} \mathrm{C}$ & $24,57^{\mathrm{a}}$ & $27,07^{\mathrm{ab}}$ & $29,03^{\mathrm{b}}$ & $28,87^{\mathrm{b}}$ & $29,43^{b}$ & $29,83^{b}$ & $28,47^{\mathrm{b}}$ & $29,93^{\mathrm{b}}$ \\
\hline Kecerahan & $\mathrm{Cm}$ & 0 & 0 & 0 & 0 & 0 & 0 & 0 & 0 \\
\hline Kekeruhan & Ppm & $3,47^{\mathrm{b}}$ & $2,4^{\mathrm{a}}$ & $21,29^{\mathrm{b}}$ & $15,37^{\mathrm{b}}$ & $5,9^{\mathrm{b}}$ & $5,2^{\mathrm{b}}$ & $4,41^{\mathrm{b}}$ & $4,26 \mathrm{~b}$ \\
\hline TDS & Ppm & $89,1^{\mathrm{a}}$ & $102,2^{\mathrm{a}}$ & $158,47^{\mathrm{b}}$ & $166,63^{c}$ & $170^{\mathrm{cd}}$ & $158,45^{\mathrm{b}}$ & $192^{c}$ & $193,1^{c}$ \\
\hline TSS & Ppm & $0,63^{a}$ & $0,57^{a}$ & $0,67^{a}$ & $0,46^{\mathrm{a}}$ & $0,38^{a}$ & $0,54^{\mathrm{a}}$ & $0,73^{a}$ & $0,54^{\mathrm{a}}$ \\
\hline $\mathrm{pH}$ & - & $6,99^{a}$ & $7,59^{b}$ & $7,68^{b}$ & $7,64^{b}$ & $7,25^{b}$ & $7,49^{b}$ & $7,71^{\mathrm{b}}$ & $7,68^{b}$ \\
\hline DO & Ppm & $5,6^{\mathrm{a}}$ & $6,67^{a}$ & $5,4^{\mathrm{a}}$ & $5,07^{\mathrm{a}}$ & $4,73^{a}$ & $5,2^{\mathrm{a}}$ & $5,73^{\mathrm{a}}$ & $4,67^{a}$ \\
\hline BOT & $\mathrm{Mg} / 1$ & $2,69^{a}$ & $5,27^{\mathrm{b}}$ & $8,32^{\mathrm{cd}}$ & $10,22^{\mathrm{e}}$ & $8,53^{d}$ & $6,69^{b c}$ & $7,58^{\mathrm{cd}}$ & $7,58^{\mathrm{cd}}$ \\
\hline Ammonia & - & $0,03^{\mathrm{a}}$ & $0,03^{\mathrm{a}}$ & $0,327^{\mathrm{b}}$ & $0,451^{\mathrm{b}}$ & $0,124^{\mathrm{a}}$ & $0,33^{\mathrm{b}}$ & $0,14^{\mathrm{a}}$ & $0,13^{\mathrm{a}}$ \\
\hline Nitrat & - & $1,18^{\mathrm{a}}$ & $4,5^{\mathrm{b}}$ & $10,38^{\mathrm{cd}}$ & $11,45^{\mathrm{d}}$ & $11,52^{\mathrm{d}}$ & $11,24^{\mathrm{cd}}$ & $9,9^{\mathrm{cd}}$ & $8,73^{c}$ \\
\hline Fosfat & - & $0,373^{\mathrm{ab}}$ & $0,217^{a}$ & $0,51^{b c}$ & $0,71^{\mathrm{d}}$ & $0,67^{\mathrm{cd}}$ & $0,72^{\mathrm{d}}$ & $0,79 d$ & $0,77^{\mathrm{d}}$ \\
\hline \multicolumn{10}{|c|}{ Status Mutu air } \\
\hline $\begin{array}{l}\text { Indeks } \\
\text { Pencemaran }\end{array}$ & $\begin{array}{l}\text { Cemar } \\
\text { ringan }\end{array}$ & $\begin{array}{l}\text { Cemar } \\
\text { ringan }\end{array}$ & $\begin{array}{l}\text { Cemar } \\
\text { ringan }\end{array}$ & $\begin{array}{l}\text { Cemar } \\
\text { ringan }\end{array}$ & $\begin{array}{l}\text { Cemar } \\
\text { ringan }\end{array}$ & $\begin{array}{l}\text { Cemar } \\
\text { ringan }\end{array}$ & $\begin{array}{l}\text { Cemar } \\
\text { ringan }\end{array}$ & $\begin{array}{l}\text { Cemar } \\
\text { ringan }\end{array}$ & $\begin{array}{l}\text { Cemar } \\
\text { ringan }\end{array}$ \\
\hline $\mathrm{FBI}^{*}$ & Buruk & $\begin{array}{l}\text { Sangat } \\
\text { buruk }\end{array}$ & $\begin{array}{l}\text { Kurang } \\
\text { baik }\end{array}$ & Buruk & $\begin{array}{l}\text { Sangat } \\
\text { buruk }\end{array}$ & $\begin{array}{l}\text { Sangat } \\
\text { buruk }\end{array}$ & $\begin{array}{l}\text { Sangat } \\
\text { buruk }\end{array}$ & Buruk & $\begin{array}{l}\text { Sangat } \\
\text { buruk }\end{array}$ \\
\hline
\end{tabular}

Keterangan : $\left({ }^{*}\right)$ : Factor Biotic Index ; sumber : Helen (2020) 
Tabel 4. Analisis Korelasi antara Vegetasi Riparian dengan Karakteristik FisikKimia Air Sungai Code.

\begin{tabular}{|c|c|c|c|c|c|c|}
\hline & & $\begin{array}{l}\text { Jumlah } \\
\text { jenis }\end{array}$ & $\begin{array}{l}\text { Jumlah } \\
\text { Individu }\end{array}$ & $\begin{array}{c}\text { Indeks } \\
\text { Kerapatan } \\
\text { Jenis }\end{array}$ & $\begin{array}{c}\text { Indeks } \\
\text { Kekayaan } \\
\text { Jenis }\end{array}$ & $\begin{array}{c}\text { Indeks } \\
\text { Keanekaragaman }\end{array}$ \\
\hline \multirow{2}{*}{$\begin{array}{l}\text { Kedalaman } \\
\text { Sungai }\end{array}$} & Pearson correlation & .245 & .032 & -.131 & .242 & .117 \\
\hline & Sig.(2-tailed) & .559 & .939 & .758 & .564 & .782 \\
\hline \multirow{2}{*}{$\begin{array}{l}\text { Kecepatan arus } \\
\text { air }\end{array}$} & Pearson correlation & -.107 & -.391 & -.500 & -.094 & -.192 \\
\hline & Sig.(2-tailed) & .801 & .339 & .207 & .824 & .648 \\
\hline \multirow[t]{2}{*}{ Debit sungai } & Pearson correlation & -.586 & -.697 & -.754 & -.538 & -.624 \\
\hline & Sig.(2-tailed) & .127 & .054 & .031 & .169 & .098 \\
\hline \multirow[t]{2}{*}{ Suhu } & Pearson correlation & -.413 & -.387 & -.486 & -.390 & -.426 \\
\hline & Sig.(2-tailed) & .310 & .343 & .222 & .339 & .293 \\
\hline \multirow[t]{2}{*}{ Kecerahan } & Pearson correlation & . & . & . & . & . \\
\hline & Sig.(2-tailed) & . & . & . & . & . \\
\hline \multirow[t]{2}{*}{ Kekeruhan } & Pearson correlation & -.712 & -.637 & -.606 & -.713 & -.767 \\
\hline & Sig.(2-tailed) & .048 & .089 & .111 & .047 & .026 \\
\hline \multirow[t]{2}{*}{ TDS } & Pearson correlation & -.232 & -.462 & -.629 & -.142 & -.281 \\
\hline & Sig.(2-tailed) & .580 & .249 & .095 & .738 & .501 \\
\hline \multirow[t]{2}{*}{ TSS } & Pearson correlation & .400 & .120 & .079 & .507 & .454 \\
\hline & Sig.(2-tailed) & .326 & .778 & .853 & .200 & .259 \\
\hline \multirow[t]{2}{*}{$\mathrm{pH}$} & Pearson correlation & -.219 & -.104 & -.201 & -.163 & -.175 \\
\hline & Sig.(2-tailed) & .603 & .806 & .633 & .700 & .679 \\
\hline \multirow[t]{2}{*}{ DO } & Pearson correlation & .170 & .399 & .507 & .198 & .327 \\
\hline & Sig.(2-tailed) & .688 & .327 & .199 & .638 & .430 \\
\hline \multirow[t]{2}{*}{ BOT } & Pearson correlation & $-.717^{*}$ & -.660 & $-.724^{*}$ & -.671 & $-.749^{*}$ \\
\hline & Sig.(2-tailed) & .045 & .075 & .042 & .068 & .032 \\
\hline \multirow[t]{2}{*}{ Ammonia } & Pearson correlation & -.613 & -.655 & -.641 & -.588 & -.621 \\
\hline & Sig.(2-tailed) & .106 & .078 & .087 & .125 & .101 \\
\hline \multirow[t]{2}{*}{ Nitrat } & Pearson correlation & -.649 & $-.715^{*}$ & $-.774^{*}$ & -.576 & -.645 \\
\hline & Sig.(2-tailed) & .082 & .046 & .024 & .135 & .084 \\
\hline \multirow[t]{2}{*}{ Fosfat } & Pearson correlation & -.099 & -.489 & -.642 & -.002 & -.154 \\
\hline & Sig.(2-tailed) & .816 & .219 & .086 & .997 & .716 \\
\hline
\end{tabular}

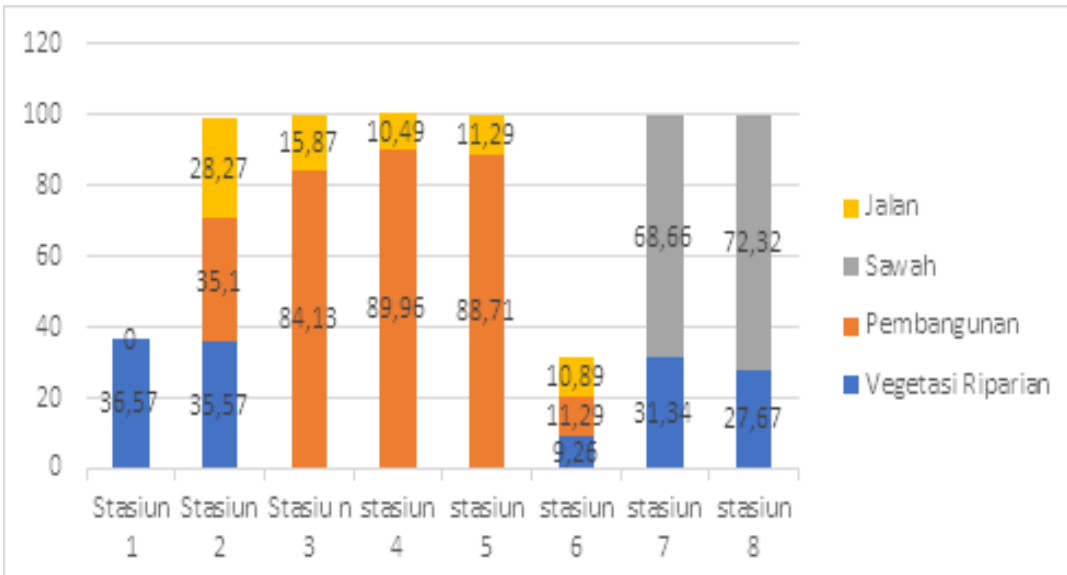

Gambar 1. Penggunaan Lahan Daerah Vegetasi Riparian dari Setiap Stasiun Pengamatan 


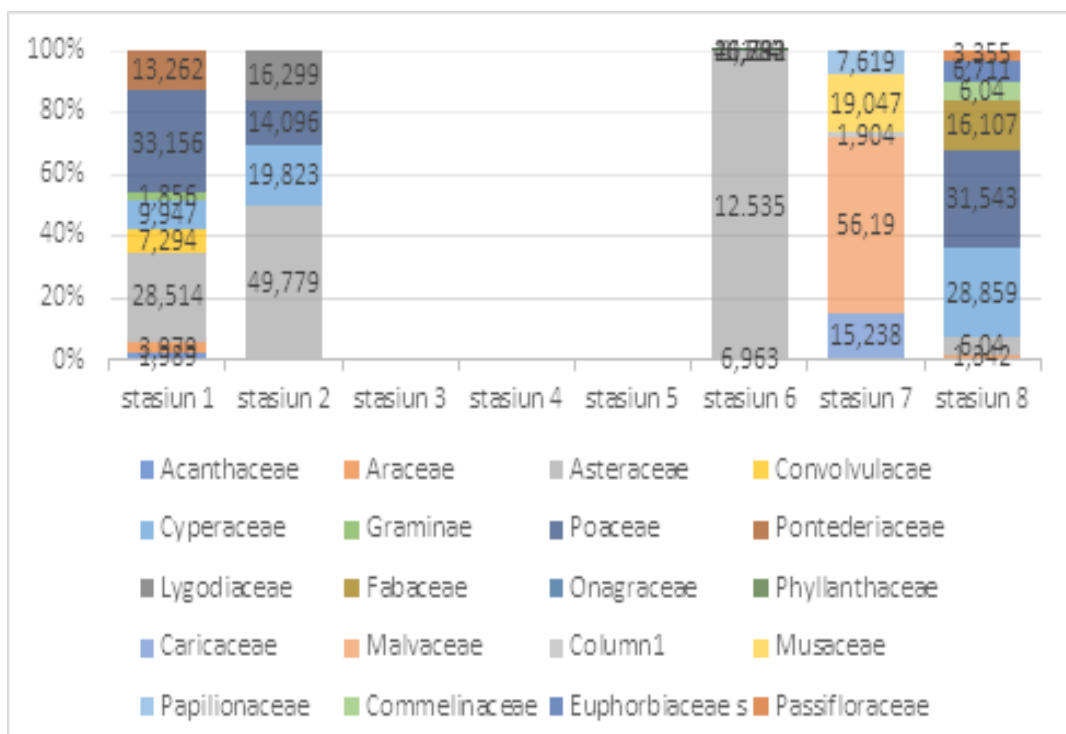

Gambar 2 Struktur vegetasi riparian sungai Code berdasarkan kelompok famili

sungai menyebutkan bahwa sempadan sungai berfungsi sebagai ruang penyangga antara ekosistem sungai dan daratan, agar fungsi sungai dan kegiatan manusia tidak saling terganggu. Batas sempadan sungai berbedabeda menurut dasar yang digunakan. Lebar sempadan sungai yang maksimal sangat jarang ditemukan, terutama di kawasan perkotaan. Lebar sempadan sungai yang maksimal merupakan kondisi ideal yang telah jarang ditemukan di Yogyakarta. Berdasarkan hasil pengamatan penggunaan lahan di sekitar sempadan sungai Code (Gambar 1), penggunaan sempadan sungai paling dominan diperuntukkan untuk pembangunan fisik (tanggul,pemukiman warga,tambak ikan, kandang ayam,dan rumah makan), diikuti secara berturutturut oleh pemanfaatan sebagai area persawahan, pemanfaatan sebagai zona vegetasi riparian dan pemanfaatan sebagai jalan. Hasil penelitian Listyaningrum et al (2017) menunjukkan bahwa penggunaan lahan di sungai Code semakin meningkat. Luas lahan terbangun pada tahun 2017 adalah 204.889,12 $\mathrm{m}^{2}$ atau meliputi $42,72 \%$ luas sempadan sungai.

Vegetasi riparian yang diteliti banyak ditemukan di daerah hulu (stasiun 1-2), tengah (stasiun 3-6) dan hilir sungai (stasiun 7-8). Vegetasi riparian tidak ditemukan di stasiun 3-5 yang terletak di Jembatan Kewek, Jembatan Sayidan dan Jembatan Keparakan.
Hal ini di sebabkan oleh adanya penggunaan lahan seperti pembangunan tanggul baik di sebelah kiri maupun sebelah kanan sungai.

Berdasarkan hasil identifikasi vegetasi ditemukan 36 spesies,25 famili, 23 ordo, 4 kelas, dan 2 divisi dengan persentase vegetasi riparian di setiap stasiun yang berbeda-beda (Gambar 2). Hal tersebut dipengaruhi oleh adanya perbedaan aktivitas manusia, penggunaan lahan,sumber pencemar dan karakteristik lingkungan aliran sungai Code. Pada stasiun 1 yang merupakan bagian hulu pengamatan terdapat familia Poaceae sebagai vegetasi dominan .Salah satu spesies dalam famili Poaceae adalah Pogonatherum paniceum yang merupakan spesies rumput. Marnix dan Langoy (2016), memyatakan bahwa spesies anggota famili Poaceae memiliki kemampuan adaptasi besar yang memungkinkan untuk tetap bertahan dalam berbagai kondisi. Spesies dari Poaceae dapat tumbuh dengan baik pada zona riparian yang lembab dan terbuka, serta tidak dapat tumbuh dengan baik di area yang kekurangan sinar matahari. Vegetasi riparian dari famili Poaceae juga tampak dominan pada stasiun 8 yang merupakan bagian hilir DAS Code. Salah satu spesies famili Poaceae yang banyak dijumpai pada stasiun 8 adalah adalah Bambusa vulgaris yang merupakan vegetasi kelompok pepohonan. Komposisi vegetasi riparian di stasiun 8 tersusun atas semak dan pepohonan. Hal ini dipengaruhi 
oleh karakterisitik lingkungan berpasir yang lembab dan terbuka.

Menurut Rahardjanto et al., (2015), indeks biotik vegetasi riparian yang baik terdiri dari tiga komponen utama yaitu indeks keragaman jenis $\left(\mathrm{H}^{\prime}\right)$, indeks kekayaan jenis (R) dan indeks kerapatan (D) (Tabel 2).

Nilai indeks $\mathrm{H}^{\prime}$ di setiap stasiun pengamatan berada pada rentang nilai 2,14 3,06. Ismaini et al. (2015) menyatakan bahwa semakin tinggi indeks keanekaragaman, maka semakin stabil ekosistem sungai.

Indeks $\mathrm{R}$ atau indeks margalef merupakan indeks yang paling sensitif dalam menunjukkan jumlah spesies yang ditemukan di setiap stasiun pengamatan. Jumlah jenis dan jumlah total individu sangat mempengaruhi besar kecilnya nilai indeks margalef pada setiap stasiun. Menurut Santoso (2016), nilai indeks margalef akan tinggi jika terdapat jumlah spesies yang tinggi sehingga kesensitifan keragaman spesies tumbuhan akan diperoleh dengan bertambahnya jumlah spesies. Nilai indeks $\mathrm{R}$ yang didapatkan di setiap stasiun dari hulu ke hilir mengindikasikan penurunan nilai,walaupun terjadi sedikit peningkatan nilai di stasiun 7 dan stasiun 8 . Hal ini terjadi karena kekayaan spesies dan jumlah individu di stasiun 7 dan stasiun 8 lebih tinggi daripada stasiun 6 dan stasiun 2,namun masih rendah daripada stasiun 1 .

Indeks D vegetasi riparian dari semua stasiun menunjukkan rentang nilai 1,00 - 1,98. Indeks D ini dapat menunjukkan gambaran mengenai skala terbesar suatu jenis vegetasi yang tumbuh pada suatu luasan area. Nilai indeks D memperlihatkan pola yang sama dengan nilai indeks $\mathrm{H}^{\prime}$ yaitu memiliki kecenderungan penurunan dari setelah meninggalkan daerah hulu sungai, namun mengalami sedikit peningkatan di stasiun 7 dan stasiun 8 yang terletak di hilir sungai.

Hasil penelitian menunjukkan adanya perbedaan signifikan pada beberapa parameter kualitas air, baik parameter fisik atau kimia di setiap stasiun seperti parameter kecepatan arus,TDS, BOT, amonia, nitrat dan fosfat. Parameter yang tidak menunjukkan adanya perbedaan signifikan adalah kedalaman, debit, suhu, kekeruhan,TSS, pH dan DO (Tabel 3).

Parameter kedalaman sungai dari hulu ke hilir menunjukkan pola flukuatif. Kedalaman sungai yang secara alamiah meningkat dari hulu ke hilir tidak dijumpai dalam pengamatan. Hal ini terjadi kemungkinan disebabkan pembangunan bantal tanggul sehingga dapat menyimpan lumpur yang terbawa dari sawah sehingga mendangkalkan sungai.

Parameter ammonia, nitrat dan fosfat, menunjukkan peningkatan dari hulu kehilir. Hal ini disebabkan karena bahan pencemaran berasal dari buangan limbah domestik dan limbah pertanian secara langsung ke badan air. Priyono et al. (2014), memberi penjelasan bahwa meningkatnya bahan pencemar di dalam air terjadi karena sungai banyak menerima limbah yang berasal dari berbagai buangan limbah rumah tangga dan pertanian. Selain meningkatkan parameter kimia air sungai, aktivitas dan sumber pencemaran juga mempengaruhi mempengaruhi parameter fisik berupa kedalaman, kecepatan arus, dan kekeruhan air sungai.

Berdasarkan hasil pengamatan penggunaan lahan di DAS Code didapatkan pola penggunaan lahan berbeda-beda (Tabel 3). Perbedaan penggunaan lahan dapat mempengaruhi kualitas air sungai Code.

Keberadaan vegetasi riparian juga dapat mempengaruhi kualitas air DAS Code. Vegetasi riparian sangat berperan dalam menjaga kualitas air sungai. Akar pohon yang berada di pinggir sungai mampu mereduksi bahan pencemar dan polutan (total senyawa organik dan non organik), mampu mengurangi padatan yang tersuspensi dan kekeruhan serta dapat mengatur cahaya matahari yang masuk ke sungai. Di lain sisi, pengamatan pada beberapa stasiun menunjukkan terdapatnya tumbuhan yang dapat menyimpan lumpur sehingga mengakibatkan pendangkalan sungai. Menurut Wilson (2010), kurangnya kecerahan perairan diakibatkan oleh adanya bahan-bahan koloid dan tersuspensi seperti lumpur, bahan organik dan anorganik. Dari hasil pengamatan didapatkan bahwa 
parameter ammonia,fosfat dan nitrat mengalami peningkatan dari hulu ke hilir DAS Code. Selain disebabkan oleh meningkatnya bahan pencemar dalam badan sungai, faktor penurunan fungsi vegetasi riparian dalam menyaring dan mengendapkan padatan yang masuk ke badan sungai juga tidak dapat disangkal. Adanya aktivitas manusia di zona riparian yang menghilangkan vegetasi seperti yang terjadi pada alih fungsi lahan sebagi tempat penambangan pasir atau alih fungsi lahan ke bentuk permanen menyebabkan juga menyebabkan fungsi penyaring vegetasi riparian menjadi hilang.

Hasil penelitian secara umum di seluruh stasiun pengamatan menunjukkan bahwa keberadaan vegetasi riparian mempengaruhi parameter kedalaman,kecepatan arus, debit, amonia, nitrat dan fosfat (Tabel 3).

Penentuanstatus mutu air menggunakan indeks pencemaran menunjukkan bahwa sungai Code masuk dalam klasifikasi cemar ringan dan sesuai standar baku mutu kelas II berdasarkan Peraturan Gubernur DIY Nomor 20 Tahun 2008 Tentang Baku Mutu Air di Daerah Istimewa Yogyakarta (Anonim, 2008). Akan tetapi, berdasarkan nilai Factor Biotic Index (FBI), kualitas air DAS Code menunjukkan status tercemar ringan. Helen (2020), menjelaskan bahwa nilai FBI dapat digunakan sebagai indikator penilaian pencemaran yang baik karena indikator yang digunakan merupakan makroinvertebrata yang memiliki suatu batas kepekaaan pencemaran yang berbedabeda antar spesies.

Hasil analisa kuantitatif pada Tabel 4 menunjukkan adanya pengaruh struktur komunitas vegetasi riparian terhadap karakteristik fisik dan kimia air sungai Code yang dibuktikan dengan adanya nilai negatif parameter bahan organik total (BOT) dan Nitrat (sig < 0,05). Jumlah jenis, indeks kerapatan jenis (D) dan indeks keanekaragamanjenis $\left(\mathrm{H}^{\prime}\right)$ memiliki pengaruh kuat terhadap pola negatif parameter BOT. Hal ini mengindikasikan bahwa semakin tinggi jumlah jenis,indeks $\mathrm{D}$ dan indeks $\mathrm{H}^{\prime}$, maka semakin rendah BOT. Hasil penelitian Prasetyo dan Retnaningdyah (2013) juga menyebutkan bahwa vegetasi riparian berperan penting dalam peningkatan kualitas air dimana vegetasi tersebut (hidromakrofita) mampu menurunkan konsentrasi BOT serta meningkatkan kadar oksigen terlarut di bagian hilir saluran irigasi.

Jumlah jenis dan indeks D memiliki pengaruh terhadap nilai negatif parameter nitratair sungai Code. Hal ini mengindikasikan bahwa semakin tinggi jumlah individu dan indeks D maka kadar nitrat air sungai akan semakin rendah. Triyoga (2019) menjelaskan bahwa proses penyerapan atau penyaringan pencemar hanya dapat terjadi jika pencemar dari daratan yang dibawa oleh aliran permukaan melalui zona riparian sebelum masuk ke sungai. Penyerapan nitrat untuk pertumbuhan tanaman merupakan mekanisme utama perpindahan nitrat dari vegetasi riparian. Vegetasi, khususnya pohon, mengubah nitrat menjadi nitrogen organik di dalam jaringan tumbuhan kemudian menyimpannya di dalam jaringan tumbuhan di atas permukaan tanah sehingga nitrogen dapat dimineralisasikan dan didenitrifikasi oleh mikroba tanah.

\section{Kesimpulan}

Struktur vegetasi riparian di daerah aliran sungai (DAS) Code didominasi oleh famili Poaceae, Asteraceae dan Malvaceae. Lahan di sekitar DAS Code banyak dimanfaatkan untuk pembangunan pemukiman, usaha pertanian dan penambangan pasir. Sumber pencemar utama DASCode berupa limbah rumah tangga mempengaruhi kualitas fisik dan kimia air sungai Code, sedangkan perbedaan struktur komunitas vegetasi riparian mempengaruhi kadar BOT dan nitrat air sungai Code dengan korelasi yang negatif. Indeks pencemaran menunjukkan sungai Code masuk dalam klasifikasi tercemar ringan dan masuk dalam kelas II sesuai Standar Baku Mutu Peraturan Gubernur Daerah Istimewa Yogyakarta tahun 2008.

\section{Daftar Pustaka}

Anonim (2003).Keputusan Menteri Negara Lingkungan Hidup No. 115 Tahun 2003 tentang Pedoman Penentuan Status Mutu Air 
Anonim. (2008). Peraturan Gubernur DIY Nomor 20 Tahun 2008 Tentang Baku Mutu Air di Daerah Istimewa Yogyakarta.

Anonim. (2011).Peraturan Pemerintah Republik Indonesia Nomor 38 Tahun 2011 tentang Sungai

Anonim.(2015). Peraturan Menteri Pekerjaan Umum dan Perumahan Rakyat Republik Indonesia Nomor 28/PRT/M/2015 tentang Penetapan Garis Sempadan Sungai dan Garis Sempadan Danau

Hellen, A., Kisworo, \& Rahardjo, D. (2020). Komunitas makroinvertebrata bentik sebagai bioindikator kualitas air Sungai Code, Prosiding Seminar Nasional Biologi di Era Pandemi COVID-19, Gowa, 19 September 2020, 294-303

Ismaini, L., Laliati, M., Rustandi., \& Sunandar D. (2015). Analisis Komposisi dan Keanekaragaman Tumbuhan di Gunung Dempo, Sumatera Selatan. Prosiding Seminar Nasional Masyarakat Biodiversity Indonesia, 1(6) September 2015, hlm. 1397-1402

Listyaningrum, N., Lestari, S.F., Riyanto, I.A, \& Cahyadi, A. (2017). Pengelolaan Sempadan Sungai Code Sebagai Upaya Pelestarian Ekosistem Daerah Aliran Sungai di Kota Yogyakarta dan Sekitarnya. Seminar Nasional III Pengelolaan Pesisir dan Daerah Aliran Sungai Yogyakarta, 26 September 2017

Marnix L.D \& Langoy, A. R. (2016). Keanekaragaman Vegetasi Riparian di Sungai Tewalen. Ilmiah Sains, 16, 8.

Prasetyo, H. D \& Retyaningdyah, C. (2013). Peningkatan Kualitas Air Irigasi Akibat Penanaman Vegetasi Riparian dari Hidromakrofita Lokal selama 50 Hari. Jurnal Biotropika, 1(4), 149-153.

Priyono, R. E., Supenah, P., \& Widyastuti, E. (2014). Kajian Kualitas Air Sungai Condong yang terkena Buangan Limbah Cair Industri Batik Trusmi Cirebon. Biosfera , 32(2), 110-118.

Rachmawati, E. T \& Retnaningdyah, C. (2014). Karakteristik Vegetasi Riparian dan Interaksinya dengan Kualitas Air Mata Air Sumber Awan Serta Salurannya di Kecamatan Singosari
Malang. Jurnal Biotropika, 2(3), 136-141 Rahardjanto, A., Kusnoputranto, H., Sutijiningsih, D., \&Seda, F. S.S.E. (2015). Simple Method to Evaluate of River Quality based on Riparian Vegetation Bioindicator. Research Journal of Science $\mathcal{E}$ IT Management. 4(5), 25-35.

Santoso Yanto, H. N. E. A. Z. (2016). Keanekaragaman Spesies Tumbuhan di Area Nilai Konservasi. Media Konservasi, 21(1), 91-98. Semiun, C. G., Arisoesilaningsih, E. \& Retnaningdyah, C., 2013. Degradation of Riparian Tree Diversity on Spring Fed Drains and Its Impacts to Water Quality, East Java. Journal of Tropical Life Science, Volume 3(2). $120-126$

Siahaan, R. (2012). Peranan Vegetasi Riparian dalam Mempertahankan Kualitas Air Sungai Cisadane [Disertasi]. Insitut Pertanian Bogor, Bogor, Indonesia.

Shoolikhah, I., Purnama, S., \& Suprayogi, S. (2014). Kajian Kualitas Air Sungai Code Propinsi Daerah Istimewa Yogyakarta. Majalah Geografi Indonesia, 28 (1), 21-31.

Triyoga, A. (2019). Struktur Komunitas Vegetasi Riparian dan Hubungannya dengan Kualitas Air Sungai Cibanten Serang Banten [Skripsi]. Universitas Kristen Duta Wacana,Yogyakarta, Indonesia.

Wenger S. (1999). A review of the scientific literature on riparian buffer width, extent and vegetation. Georgia: Institute of Ecology, University of Georgia

Wilson, P. C. (2010). Water Quality Notes: Water Clarity (Turbidity, Suspended Solids, and Color). Department of Soil and Water Science. University of Florida. 